\title{
PENGARUH VARIASI KOLOM PASIR SEBAGAI DRAINASE VERTIKAL DUA ARAH PADA TANAH LUNAK
}

\author{
Herizki Trisatria1), Bambang Setiawan ${ }^{2)}$, Noegroho Djarwanti ${ }^{3)}$ \\ 1)Mahasiswa Program Studi Teknik Sipil Fakultas Teknik Universitas Sebelas Maret \\ 2), 3)Dosen Program Studi Teknik Sipil Fakultas Teknik Universitas Sebelas Maret \\ J1. Ir. Sutami 36 A, Kentingan, Surakarta 57126, Telp (0271) 647069, Fax 662118 \\ Email : herizki.trisatria@gmail.com
}

\begin{abstract}
The residential sector is important for a country with a large population. Indonesia in some areas has soft soil structures that tend to be unstable to support the load. The use of prefabricated vertical drain (PVD) becomes a solution to accelerate the occurrence of consolidation but requires a high cost. Vertical drain using sand columns becomes one of the low cost alternatives. The aim of this research is to know the influence of sand column as vertical drain on soft soil settlement per day. The study was conducted within 21 days with a two-way drainage direction with the addition of sand on the surface and the base. The sand column design used is single and group with $25 \mathrm{~cm}$ depth. Daily observational data are supported by water content testing on sand and soil. The settlement of sand column on group showed 31,54\% bigher than modeling with single column. The compression index $\left(C_{c}\right)$ and consolidation coefficient $\left(C_{v}\right)$ value before the test were 0,40 and $0,19 \mathrm{~cm}^{2} /$ second. After testing, the fastest settlement is sand column on group with $C_{c}$ and $C_{v}$ values of 0,63 and 0,034 $\mathrm{cm}^{2} /$ second. The addition of sand column vertical drain can affect the speed of settlement on soft soil.
\end{abstract}

Keywords : soft soil, sand column, settlement

\begin{abstract}
Abstrak
Sektor pemukiman merupakan hal yang penting bagi sebuah negara dengan jumlah penduduk yang banyak. Indonesia di beberapa wilayahnya memiliki struktur tanah lunak yang cenderung tidak stabil menopang beban. Penggunaan prefabricated vertical drain (PVD) menjadi sebuah solusi untuk mempercepat terjadinya konsolidasi namun membutuhkan biaya yang tinggi. Drainase vertikal menggunakan kolom pasir menjadi salah satu alternatif dengan biaya yang cukup murah. Penelitian bertujuan untuk mengetahui pengaruh variasi kolom pasir sebagai drainase vertikal pada tanah lunak terhadap kecepatan penurunan per hari. Penelitian dilakukan dalam durasi 21 hari dengan arah drainase dua arah dengan penambahan pasir pada permukaan dan dasar pemodelan. Pola kolom pasir yang digunakan adalah tunggal dan kelompok sedalam $25 \mathrm{~cm}$. Data pengamatan penurunan setiap hari didukung oleh pengujian kadar air pada pasir dan tanah. Uji penurunan pada pola kolom kelompok menunjukkan penurunan 31,54\% lebih tinggi dibandingkan pada model kolom tunggal. Uji konsolidasi dilakukan sebelum dan sesudah pengamatan penurunan. Nilai indeks pemampatan $\left(C_{c}\right)$ dan koefisien konsolidasi $\left(C_{v}\right)$ sebelum pengujian sebesar 0,40 dan $0,19 \mathrm{~cm}^{2} /$ detik. Setelah pengujian, indikasi penurunan tercepat adalah dengan pola kolom kelompok dengan nilai $C_{c}$ dan $C_{v}$ sebesar 0,63 dan 0,034 $\mathrm{cm}^{2} /$ detik. Penambahan drainase vertikal kolom pasir dapat mempengaruhi kecepatan penurunan tanah lunak.
\end{abstract}

Kata kunci : tanah lunak, kolom pasir, penurunan

\section{PENDAHULUAN}

Sektor pembangunan perumahan di Indonesia menjadi hal yang penting untuk dikembangkan dikarenakan populasi manusia yang semakin hari semakin berkembang pesat. Lahan yang memiliki tanah lunak tentu kurang stabil dan kurang cocok untuk dibangun. Permasalahan stabilitas tanah lunak sebagai lapisan tanah dasar sebuah bangunan dapat diperbaiki dengan menggunakan drainase vertikal. Penggunaan prefabricated vertical drain (PVD) sudah teruji dan banyak digunakan pada pembangunan proyek-proyek besar pada lahan yang luas.. Pembangunan rumah-rumah oleh warga tidak perlu menggunakan PVD karena membutuhkan biaya yang cukup mahal.

Hal ini menjadi dasar untuk membuat suatu gagasan untuk menggunakan kolom-kolom pasir sebagai penyerap air yang ada di dalam tanah lunak. Jenis drainase vertikal kolom pasir ini juga berguna untuk mempercepat terjadinya settlement. Pertimbangan menggunakan bahan pasir yaitu bahan ini mudah ditemukan di Indonesia dan terhitung murah untuk dibeli. Metode ini terhitung ekonomis dan efisien karena dapat dicari dan dibeli dengan mudah serta dapat digunakan dimana saja.

\section{TINJAUAN PUSTAKA}

Pekerjaan tanah dalam suatu konstruksi sangat penting ditinjau lebih lanjut seperti yang dinyatakan oleh Abadi (2004) "penggunaan drainase vertikal telah sejak lama dilakukan orang. Material yang menjadi bahan utama pengisi drainase vertikal pada saat itu adalah pasir. Tujuan utamanya adalah mempercepat proses penurunan yang akan terjadi pada suatu lapisan tanah tertentu. Penurunan akan cepat terjadi apabila dipasang suatu sistem drainase vertikal untuk memperpendek jarak yang ditempuh air terdisipasi”.

Dimas (2015) menjelaskan bahwa semakin besar diameter kolomnya nilai koefisien konsolidasi (Cv) semakin naik, sedangkan semakin besar diameter kolomnya nilai indeks pemampatan $(C c)$ dan penurunan konsolidasi $(S c)$ semakin 
turun. Semakin dekat jarak antar kolom, nilai koefisien konsolidasi (Cv) nya semakin naik sehingga waktu yang dibutuhkan untuk konsolidasi semakin cepat.

Penelitian oleh Listyawan dkk, (2015) mengenai pengaruh kolom pasir terhadap konsolidasi tanah lunak. Kolom pasir diletakan pada tepi timbunan tanah lunak kemudian diambil sampel dari jarak tertentu dari kolom pasir. Hasil yang didapatkan dari penelitian ini menunjukan semakin jauh sampel yang diambil dari kolom pasir kecepatan konsolidasi (Cv) semakin menurun

\section{METODE PENELITIAN}

Metode penelitian berupa eksperimental laboratorium dalam skala kecil. Tujuan dari penelitian adalah untuk mengetahui penurunan (settlement) yang terjadi pada tanah lunak bila diberi drainase vertikal kolom pasir. Penelitian ini juga memberi gambaran berapa banyak kadar air pada tanah dan pasir setiap harinya melalui pengujian water content dan pengujian hambatan listrik.

Pemodelan yang dibuat adalah variasi dengan perkuatan drainase vertikal dua arah dengan variasi bentuk kolom pasir kelompok dan tunggal. Kedua pemodelan diuji dengan dua pengujian yaitu penurunan (Settlement) dan uji kadar air pasir permukaan dan tanah. Pengujian dilakukan setiap hari selama 21 hari.

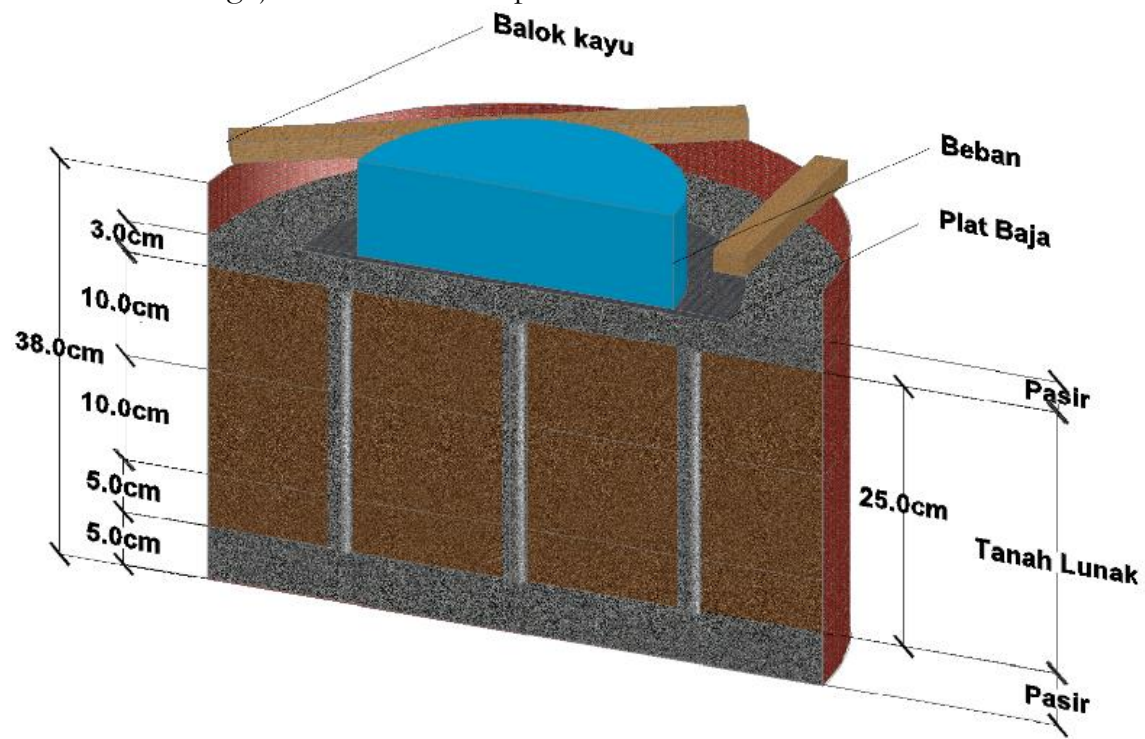

(a) Drainase vertikal dua arah kolom kelompok

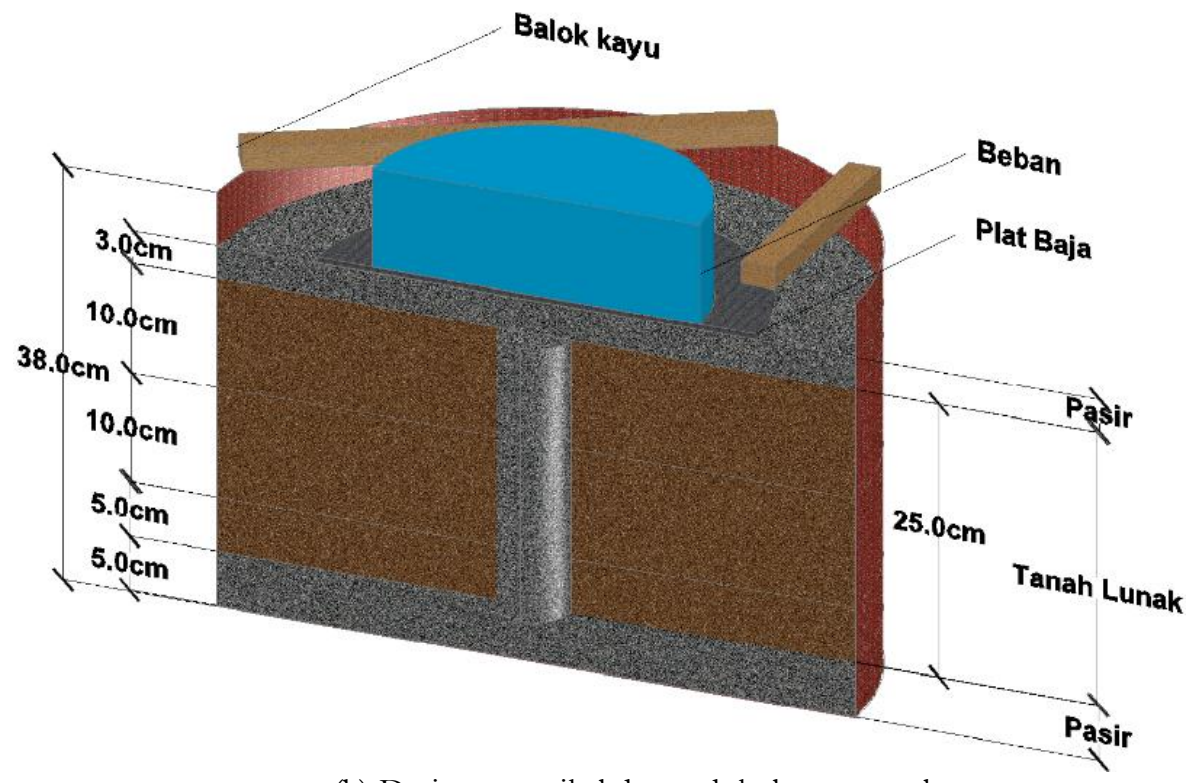

(b) Drainase vertikal dua arah kolom tunggal

Gambar 1. Pemodelan dengan perkuatan drainase vertikal 
Gambar 1. menunjukkan variasi model kolom pasir sebagai drainase vertikal yang digunakan dalam penelitian. Kedalaman tanah yang digunakan adalah sebesar $25 \mathrm{~cm}$. Pemodelan yang digunakan adalah dengan variasi drainase vertikal kolom pasir kolom kelompok dan kolom tunggal yang ditunjukkan pada gambar (a) dan (b).

a. Persiapan media tanah

Media tanah yang digunakan dalam penelitian ini adalah tanah lunak yang diambil dari desa Sumberlawang Kabupaten Sragen dengan sistem pengambilan sampel tanah terganggu (disturbed sample). Persiapan media tanah ini dilakukan dengan langkah-langkah sebagai berikut:

1. mengambil media tanah dengan cangkul dan linggis kemudian menyimpan sampel tanah ke dalam kantong plastik (Plastic bag) untuk menjaga kondisi tanah agar tetap seperti kondisi pada saat pengambilan,

2. menyimpan sampel tanah di tempat yang teduh untuk menjaga kadar air dan kelembaban tanah, setelah itu tanah dimasukkan ke drum pengujian.

Pada setiap drum pemodelan kadar air tanah lunak diusahakan dalam kondisi sama. Usaha yang dilakukan yaitu dengan menghitung kadar air pada setiap tanah pada plastic bag yang dimasukkan ke dalam drum uji. Kadar air yang diharapkan adalah $60 \%$ pada setiap plastik. Tanah yang kurang persentase kadar airnya perlu ditambahkan air kembali hingga mencapai kadar air yang diharapkan. Setelah dimasukkan ke dalam drum uji, tutup permukaan atas drum dengan plastik tebal yang kedap air agar tanah dalam kondisi yang relatif sama.

b. Persiapan alat dan bahan

Mekanisme pembuatan model uji dengan sistem drainase dua arah adalah sebagai berikut:

1. melapisi pasir pada dasar drum dengan lapisan pasir setebal $5 \mathrm{~cm}$,

2. memasukkan tanah ke dalam drum setiap $5 \mathrm{~cm}$ di isi dengan tanah seberat $20,5 \mathrm{~kg}$,

3. menumbuk tanah dan memadatkannya hingga mencapai tinggi yaitu $30 \mathrm{~cm}$,

4. membuat lubang-lubang untuk perletakan sand column dengan pipa stainless steel diameter $25 \mathrm{~mm}$ dan kedalaman $250 \mathrm{~mm}$ pada setiap jarak $165 \mathrm{~mm}$ untuk variasi kolom pasir kelompok, dan stainless steel diameter $65 \mathrm{~mm}$ dan kedalaman $250 \mathrm{~mm}$ di tengah drum uji untuk variasi kolom pasir tunggal. Lubang yang dibuat diusahakan benarbenar pada posisi vertikal dan tegak lurus dari permukaan tanah,

5. memasukan pasir kedalam lubang yang telah dibuat,

6. menambahkan lapisan pasir pada permukaan tanah dengan ketebalan $3 \mathrm{~cm}$,

7. meletakkan pelat baja berbentuk lingkaran dengan ketebalan $4 \mathrm{~mm}$ dengan diameter $40 \mathrm{~cm}$ di atas permukaan lapisan pasir.

Pengujian dilakukan setelah dipasang balok kayu di atas drum sebagai acuan pengukuran titik pelat menggunakan jangka sorong. Beban berupa ember berisi tanah diletakkan diatas pelat baja hingga total beban $40 \mathrm{~kg}$. Pengambilan data dilakukan secara pengamatan berkala terhadap beberapa hal antara lain:

1. Pengujian penurunan tanah (Settlement)

Pengukuran penurunan dilakukan dengan mengukur jarak antara balok acuan dan titik tertentu pada pelat baja menggunakan jangka sorong digital, sehingga setiap harinya akan ada perubahan jarak. Selisih dari jarak sesudah dengan jarak sebelumnya merupakan penurunan yang terjadi pada tanah.

2. Pengujian kadar air pasir permukaan dan tanah

Pengukuran kadar air dilakukan dengan mengambil sampel pasir permukaan dan tanah. Selama 21 hari pengujian dilihat perubahan kadar air yang terjadi setiap hari.

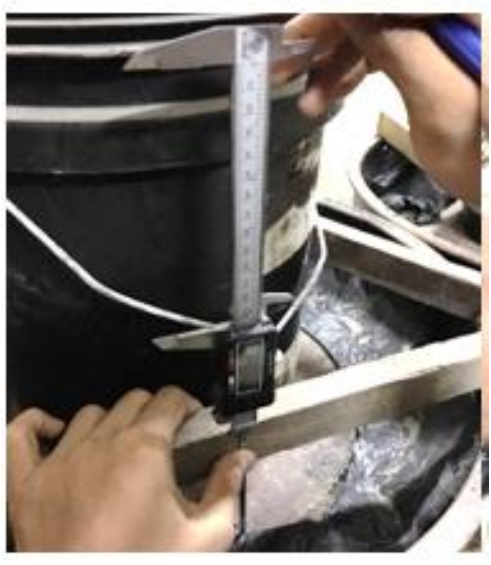

(a)

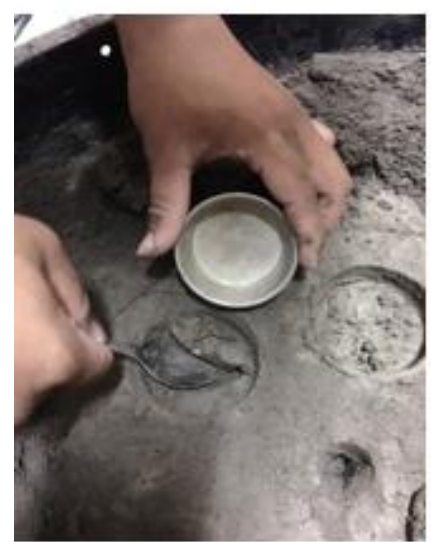

(b)

Gambar 2. Pelaksanaan pengujian penurunan dan pengambilan data (a) Pengukuran penurunan dengan jangka sorong (b) Pengambilan sampel kadar air pasir dan tanah 
Gambar 2. menunjukkan cara pengambilan data pengujian penurunan muka tanah dan kadar air. Gambar (a) pengambilan data penurunan setiap hari dengan menggunakan jangka sorong. Gambar (b) pengambilan data kadar air pasir dan tanah dengan mengambil sampel.

\section{HASIL DAN PEMBAHASAN}

Pengujian Penurunan

Hasil pengujian penurunan muka tanah dari variasi pemodelan dengan perkuatan drainase vertikal dapat dilihat pada Gambar 3. dibawah ini.

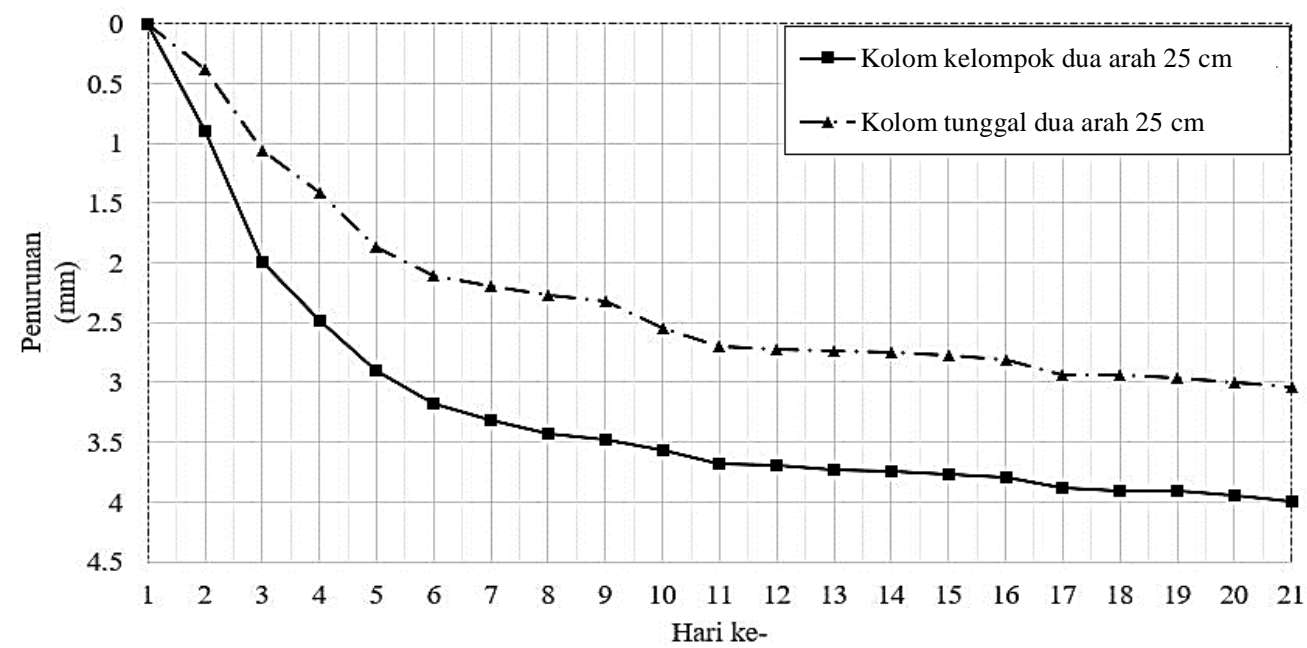

Gambar 3. Penurunan akumulatif hasil pengujian

Gambar 3. menunjukkan data penurunan tanah akumulatif setiap hari dalam pengujian. Pengujian pada variasi kolom kelompok pada hari ke-1 hingga ke-5 memperlihatkan penurunan yang signifikan dengan rata-rata penurunan sebesar $0,7258 \mathrm{~mm}$ per hari. Penurunan pada hari ke-5 hingga ke-11 memiliki rata-rata penurunan per hari sebesar 0,1294 mm. Pengujian pada variasi drainase vertikal kolom tunggal pada pengujian hari ke-1 hingga ke-6 terlihat mengalami penurunan yang besar dengan rata-rata penurunan sebesar $0,4220 \mathrm{~mm}$ per hari. Penurunan pada hari ke-7 hingga ke11 masih terus menurun namun tidak signifikan dan memiliki rata-rata penurunan per hari sebesar 0,1320 mm. Kedua variasi pemodelan terlihat mengalami asimtot dimulai hari ke-11 hingga ke-21 dengan rata-rata penurunan per hari untuk kolom kelompok sebesar 0,0310 $\mathrm{mm}$ dan kolom tunggal sebesar 0,0442 $\mathrm{mm}$. Penggunaan drainase vertikal kolom kelompok dan tunggal dua arah memiliki besar penurunan akhir masing-masing sebesar 3,99 mm dan 3,03 mm. Drainase vertikal kolom kelompok memiliki besar penurunan 31,54 \% lebih tinggi dari pada drainase vertikal kolom tunggal.

\section{Pengujian Kadar Air}

Hasil pengujian kadar air pasir permukaan dapat dilihat pada Gambar 4. dan pengujian kadar air pada tanah dapat dilihat pada Gambar 5. berikut ini. 


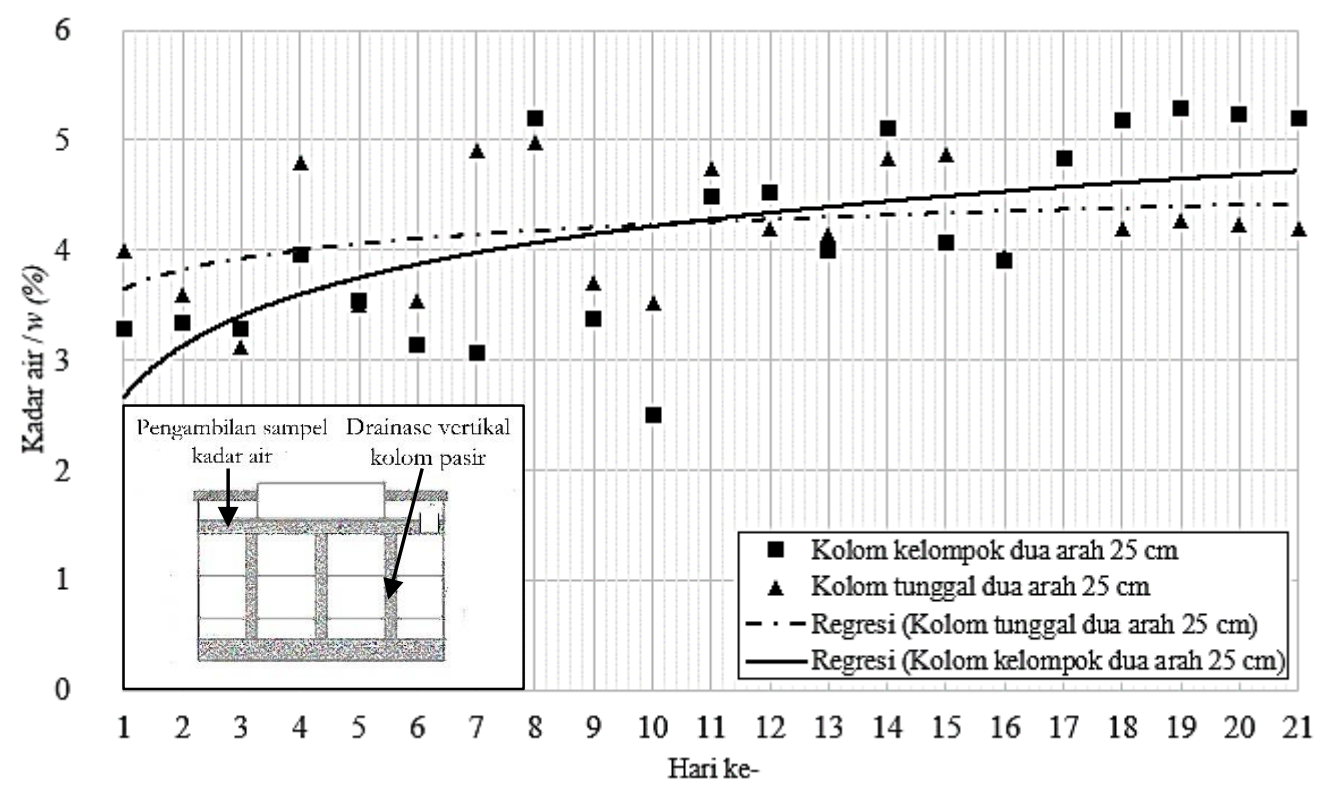

Gambar 4. Hasil uji kadar air pasir permukaan

Gambar 4. menunjukkan bahwa nilai kadar air pasir masing-masing variasi mengalami peningkatan selama pengujian dan memperlihatkan perubahan kadar air yang berbeda. Grafik pada variasi kolom kelompok dan tunggal memperlihatkan bahwa kenaikan kadar air dari awal hingga akhir pengujian cukup tinggi. Kadar air pasir pada hari ke18 hingga ke-21 terlihat telah cenderung mendatar. Margin perbedaan nilai tertinggi dan terendah yaitu 1,86\% untuk kolom kelompok, dan untuk kolom tunggal sebesar 1,71\%. Nilai kadar air rata-rata dari variasi kolom kelompok sebesar 4,12\%. dan kolom tunggal sebesar 4,19\%. Peningkatan kadar air yang cukup signifikan terjadi pada model variasi kolom kelompok. Sedangkan untuk variasi kolom tunggal cenderung mendatar namun tetap terdapat kenaikan kadar air. Seluruh pemodelan menunjukkan grafik menuju asimtot di akhir pengujian.

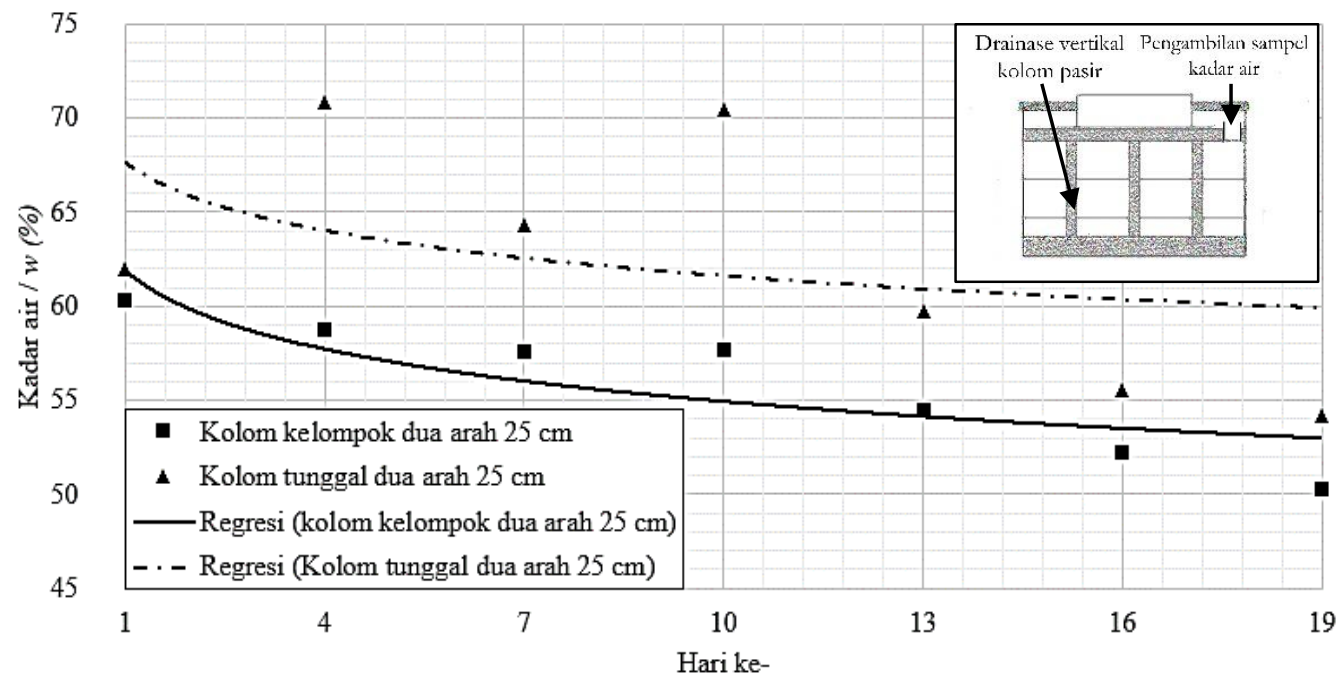

Gambar 5. Hasil uji kadar air tanah

Gambar 5. di atas menunjukkan bahwa nilai kadar air tanah mengalami penurunan selama pengujian. Variasi kolom kelompok memiliki kadar air yang menurun dari angka awal 60,27\% menuju angka 50,24\% dan mengalami penurunan sebesar 10,02\%. Variasi kolom tunggal memiliki kadar air yang menurun dari hasil awal 61,95\% dan menurun ke $54,71 \%$ dan mengalami penurunan sebesar 7,79 . Seluruh pemodelan menunjukkan grafik yang menuju asimtot di akhir pengujian.

Hubungan Penurunan dengan Kadar Air Pasir Permukaan

Seluruh data hasil pengujian pengamatan penurunan tanah dan kadar air pada pasir permukaan pada kedua model uji dapat dihubungkan menjadi sebuah grafik yang ditunjukkan pada Gambar 6. 


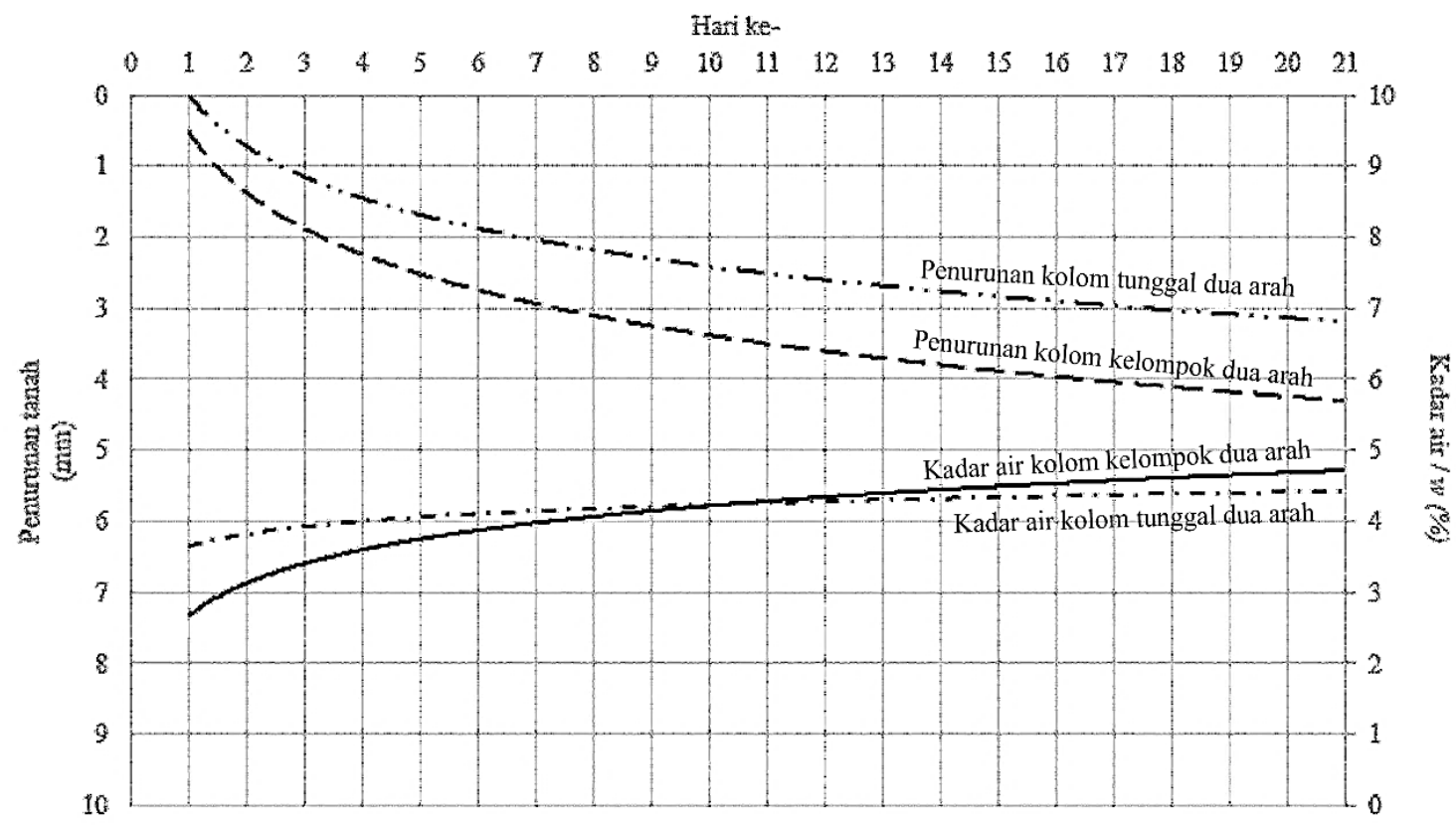

Gambar 6. Hubungan penurunan tanah dengan kadar air pasir permukaan

Gambar 6. menunjukkan grafik regresi dari data hasil penurunan muka tanah dan kadar air pasir permukaan. Terlihat selama 21 hari pengujian penurunan tanah mulai menuju asimtot, begitu juga pada grafik dari kadar air pasir permukaan. Grafik pada pemodelan drainase vertikal kolom kelompok mulai menuju asimtot horizontal di hari ke18 untuk kadar air dan penurunan pada hari ke-18. Pemodelan drainase vertikal kolom tunggal memiliki grafik kadar air yang mulai menuju asimtot horizontal di hari ke-12 dan grafik penurunan pada hari ke-16. Grafik menunjukkan bahwa seiring berjalannya pengujian penurunan, kadar air pada pasir permukaan akan meningkat seiring terkompresinya tanah lunak oleh bantuan beban bersama drainase vertikal dan permukaan tanah akan mengalami penurunan.

Nilai Indeks Pemampatan $(C c)$

Hasil rekapitulasi nilai indeks pemampatan $(C c)$ dari masing-masing model pengujian dapat dilihat pada dalam bentuk grafik pada Gambar 7.

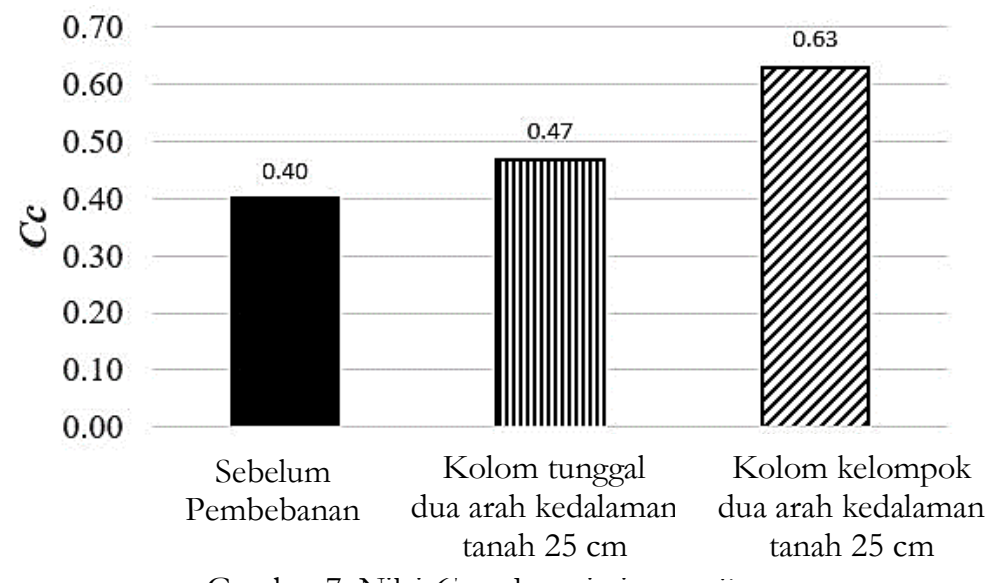

Gambar 7. menunjukkan bahwa nilai $C_{c}$ pada sebelum pengujian adalah sebesar 0,40 . Nilai Koefisien kompresi $\left(C_{c}\right)$ pada drum uji setelah pembebanan dengan drainase vertikal dua arah kolom tunggal adalah sebesar 0,47 dan pada drum uji dengan drainase vertikal dua arah kolom kelompok adalah sebesar 0,63. Terlihat dari hasil $C_{c}$ masing-masing, bahwa nilai $C_{c}$ meningkat dari awal sebelum dilakukan pengujian dan setelah dilakukan pengujian pembebanan dengan beda variasi drainase vertikal. Drum uji dengan variasi drainase vertikal dua arah kolom kelompok telah mengalami pemampatan yang terbesar sehingga memiliki nilai $C_{c}$ tertinggi.

\section{Nilai Koefisien Konsolidasi $(C V)$}


Hasil rekapitulasi nilai koefisien konsolidasi $(C v)$ dari masing-masing model pengujian dapat dilihat pada dalam bentuk grafik pada Gambar 8.

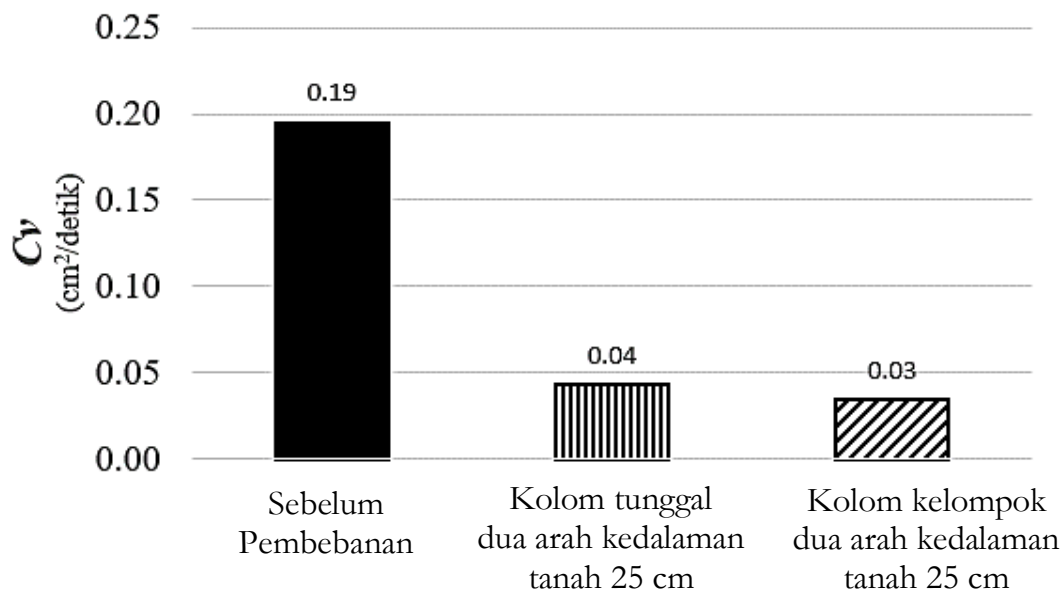

Gambar 8. Nilai $C v$ pada variasi pengujian

Gambar 8. menunjukkan bahwa nilai $C_{v}$ pada sebelum pengujian adalah sebesar $0,195 \mathrm{~cm}^{2} /$ detik. Nilai koefisien konsolidasi $\left(C_{v}\right)$ pada drum uji setelah pembebanan dengan drainase vertikal dua arah kolom tunggal adalah sebesar $0,043 \mathrm{~cm}^{2} /$ detik dan pada drum uji dengan drainase vertikal dua arah kolom kelompok adalah sebesar $0,034 \mathrm{~cm}^{2} / \mathrm{detik}_{\text {. }}$ Terlihat dari hasil $C_{v}$ masing-masing, bahwa nilai $C_{v}$ menurun dari awal sebelum dilakukan pengujian dan setelah dilakukan pengujian pembebanan dengan beda variasi drainase vertikal. Variasi kolom kelompok memiliki nilai $C_{v}$ yang rendah dan menandakan bahwa proses settlement tanah sudah akan berhenti. Drum uji dengan variasi drainase vertikal dua arah kolom kelompok mengalami penurunan terbesar sehingga ketika dilakukan uji konsolidasi hanya mengalami sedikit penurunan.

\section{KESIMPULAN}

Kesimpulan yang dapat diambil dari penelitian ini antara lain:

1. Penambahan drainase vertikal dengan variasi kolom kelompok meningkatkan kecepatan penurunan sebesar 3,99 $\mathrm{mm}$, sedangkan drainase vertikal dengan kolom tunggal meningkatkan kecepatan penurunan sebesar 3,03 mm, penambahan drainase vertikal mempercepat penurunan tanah.

2. Drainase vertikal dengan variasi kolom kelompok memiliki kecepatan 31,54\% lebih cepat dibanding drainase vertikal dengan variasi kolom tunggal, dalam penggunaan drainase vertikal kolom kelompok penurunan semakin cepat.

3. Penurunan tanah diiringi dengan meningkatnya kadar air lapisan pasir dan penurunan kadar air tanah pada setiap variasi pemodelan drainase vertikal.

\section{REFERENSI}

Abadi, T. C., 2004, Uji Laboratorium Pemanfaatan Serabut Kelapa dan Ijuk Sebagai Bahan Drainase Vertikal Tanpa Filter, Jurusan Teknik Sipil, Institut Teknologi Nasional Bandung.

Hardiyatmo, H. C., 2015. Geosintetik. Untuk Rekayasa Jalan Raya: Perancangan Dan Aplikasi. Yogyakarta: Gadjah Mada University Press.

Listyawan, A.B., Wiqoyah, Q., Renaningsih, dan Satriyana, 2015, Pengarub Kolom Pasir Terbadap Konsolidasi Tanah Lempung Lunak, Program Studi Teknik Sipil, Universitas Muhammadiyah Surakarta.

Dimas, 2015. Pengaruh Variasi Diameter Kolom Campuran Pasir Kapur Terhadap Konsolidasi Tanah Lempung Lunak, Jurusan Teknik Sipil, Universitas Muhammadiyah Surakarta. 